\title{
Chapter 9 \\ Community by Template? Considering the Role of Templates for Enacting Membership in Digital Communities of Practice
}

\author{
Juliane Jarke
}

\subsection{Introduction}

The idea of 'communities of practice' was one of the most successful to travel from academic research into the world of business and management. Originally an analytical concept to investigate learning as a social and situated practice (Lave and Wenger 1991), it became a prescriptive term and desirable objective: managers came to view communities of practice as a 'supplementary organizational form' and were increasingly seeking 'to develop and support communities of practice as part of their knowledge management strategies' (Roberts 2006, p. 626).

The rising interest by management scholars was instigated by Brown's and Duguid's account (1991) of Julian Orr's PhD research and subsequent seminal book Talking about Machines (1996). Orr had demonstrated in his ethnography how vital informal knowledge was for getting work done effectively by following the knowledge sharing practices of a community of XEROX photocopy repair technicians. Based on Orr's insights, Brown and Duguid took the concept of 'communities of practice' into the business context and promoted it as a way to leverage what organisations knew. Subsequently, management and organisational researchers set out to study to what extent communities of practice could be 'cultivated' (e.g. Wenger et al. 2002). For example, following on his work with Jean Lave, Etienne Wenger moved towards a consultancy role and argued that the 'success of organizations depends on their ability to design themselves as social learning systems' (2000, p. 225). This claim related to organisations such as private businesses but also public sector organisations and civil society organisations.

\footnotetext{
J. Jarke $(\bowtie)$

Institute for Information Management Bremen (ifib) \& Centre for Media, Communication and Information Research (ZeMKI), University of Bremen, Bremen, Germany

e-mail: jarke@uni-bremen.de
} 
In such 'social learning systems' knowledge came to be seen as a 'thing' or 'shared object' that circulates within and between communities and needs to be organised and managed (Vann and Bowker 2004; Easterby-Smith and Lyles 2011). Key to enabling the cultivation of community was some kind of 'community knowledge pool' (Lesser and Storck 2001) in which members share documents, templates, and other knowledge artefacts. Such artefacts (or knowledge objects more broadly) may then be part of a 'common body of knowledge' (du Plessis 2008) along with tools, methodologies, and approaches. Hence, most of the attention in the business and management literature focussed on how communities of practice may be created and nurtured: community came to be regarded as an organisational form for enabling relationships between distant practitioners; 'knowledge objects' (as shared objects) needed to circulate through such communities and provide a 'container' for members' shared practices (Brandi and Elkjaer 2011; Østerlund and Carlile 2005; Cox 2005). ${ }^{1}$

Hence so far, knowledge objects have been understood as a means for community members to share their communal practice. What has received less attention is the role of knowledge objects in the performance of community membership. I argue in the following that the development and continuous reconfiguring of communal 'knowledge objects' can be understood as a way to grow community. The idea of circulating objects to perform community is prominent within anthropology. Miller (2010) describes the exchange of goods 'as a means to grow culture' (p. 10). Accordingly, in order to consider digital forms of togetherness, digital communities may not be regarded as a medium constructed for enabling relationships between distant practitioners, but exchange relationships between individuals are a means to grow community because, as Miller (2011, p. 207) argues, community is 'a series of increasingly expanding exchanges'. The work performed around the construction and negotiation of knowledge objects is a way for individuals to enact their membership and foster a sense of belonging and identity. Hence, community is not a medium for circulating knowledge objects; rather the configuring and circulation of knowledge objects enacts community. In this chapter, I argue that the creation and collection of knowledge objects are not simply an act of developing a 'common body of knowledge', and as such a by-product of the performance of community, but rather they are key to enacting membership in trans-local communities and hence perform community.

This chapter focuses on a specific and very common type of knowledge object in trans-local communities: templates. I demonstrate that templates for describing a community's shared practice are a way to enable 'exchange relations' between community members and foster their sense of belonging and identity. The chapter is based on a 3-year ethnographic study of a European Commission initiative: ePractice. ePractice set out to create (or nurture) a 'European eGovernment

\footnotetext{
${ }^{1}$ Different forms of such trans-local communities have been described and analysed, including concepts such as 'epistemic communities' (Haas 1992), 'virtual communities' (Cox 2005), or 'communities of interest' (Fischer 2001).
} 
community of practice' in which eGovernment practitioners ${ }^{2}$ would be enabled to share their experience and expertise across a number of topics related to eGovernment via online and offline means. This striving for community is well established throughout the European Commission and it follows this endeavour in the many different policy fields it works on (Jarke 2015). ${ }^{3}$ Yet after establishing a European endeavour to strive for community, the question arises: what kind of community shall it be, as there are many ways of 'doing' community. In the case of ePractice, the 'community of practice' concept provided a solution to the question of how to do a 'European eGovernment community' well. As such, it has informed the way in which the European Commission and other actors conceived of ePractice and configured it-how they aimed to cultivate ePractice. Templates for describing eGovernment practices in a structured way became one of the main tools to facilitate the sharing of practices amongst geographically distributed practitioners. Through templates, the ePractice team strived to create a common European knowledge base on eGovernment.

In order to discuss the role that templates (for capturing and circulating practices) may play in the performance of digital community, we need to consider how practice relates to the performance of community and membership. In the following, I provide a theoretical framing for this question. I then present the ePractice case study and analyse the role of templates for the cultivation of this community. Subsequently I discuss my findings and argue that knowledge objects (such as templates) are key for performing membership in trans-local communities.

\subsection{Theoretical Framework}

\subsubsection{Performing Community Through Travelling Practices}

Originally, the 'community of practice' concept provided a conceptual space to investigate learning as a social and situated practice. With their monograph, Jean Lave and Etienne Wenger (1991) challenged the traditional view according to which learning is primarily understood cognitively, as happening in the mind of the learner. In contrast to this traditional 'schooling model', Lave's and Wenger's approach conceptualises learning as taking place not in an individual mind but in a participation framework, as a mode of being in the world and everyday practice. Legitimate peripheral participation hereby refers to a framework describing how roles within a community are defined and how engagement may take place.

\footnotetext{
${ }^{2}$ eGovernment or electronic government refers to the use of electronic technologies within the public sector. It comprises inter-governmental communication and workflow-design as well as communication between government and citizens, and government and businesses. More information is provided in the methodology section.

${ }^{3}$ European community-building relates to policy fields such as climate change, biodiversity, or-as was the case for this ethnography-eGovernment.
} 
According to this framework, community as well as practice were conceptualised as intrinsically local. However, both concepts have also gained enormous importance in considerations of digital forms of togetherness. Through the proliferation of digital technologies across social life, the performance of community has increasingly become a distributed accomplishment. With the rising entanglement of information and communication technologies (ICTs) in organising everyday life and work activities, scholars as well as practitioners set out to translate concepts such as 'communities of practice' into ICT-mediated, digital environments (e.g. Brown and Duguid 2001; Vaast and Walsham 2009): the 'communities of practice' concept, developed as an analytical tool to research learning as a situated and 'legitimate' participation in a communal practice, came to be translated into a prescriptive term that designated a desirable objective within distributed, digital settings (e.g. Lave 2008; Amin and Roberts 2008; Cox 2005).

A concept originally intended as a 'way of looking' at learning as a situated practice became 'a thing to look for' (Lave 2008, p. 290). Suddenly organisations were seen as assemblages of communities that could be cultivated in order to leverage the benefits and opportunities associated with the idea of 'communities of practice'. Amin and Roberts (2008) note that

[a]s the race for survival in the knowledge economy intensified, so too seems the desire to exploit the potential for creativity and innovation offered by CoPs [communities of practice], ever wishful of articulating and harnessing the intangible, the tacit and the practiced. (p. 354)

For example, Swan, Scarbrough and Robertson (2002) have described the appropriation of the concept in the business context in their analysis of a company where managers purposefully use "“communities of practice" as a rhetorical device to enrol key professionals and to mobilize and legitimize changes in work practices' (p. 477).

One of the very first initiatives to establish or build a trans-local community of practice was the EUREKA-project at XEROX, an initiative that aimed at enabling and enhancing knowledge sharing amongst XEROX' photocopy repair technicians. The starting point of the project was that much of the informal or 'tacit' knowledge 'remains embedded in practice' within small circles of colleagues and work groups (Bobrow and Whalen 2002, p. 47). Insights from studies such as Orr's and Lave's and Wenger's led to considerations about how organisations may facilitate and further knowledge sharing beyond local groups:

\footnotetext{
Organizations face the challenge of somehow converting this valuable but mainly local knowledge into forms that other members of the organization can understand and perhaps most important, act on. (Bobrow and Whalen 2002, p. 47)
}

The EUREKA project was meant to accomplish this. In EUREKA, technicians wrote tips for other technicians that were moderated and approved by 'expert field technicians'. What a project such as EUREKA struggled with was the extent to which informal and local talking and telling could be formalised and even centrally managed in a 'tip data base' (Bobrow and Whalen 2002, p. 52). For example, Orr (2006) highlighted that one of the problems that was never anticipated was that ' $[\mathrm{t}]$ echnicians did not all find it natural to write, nor did they find it natural to abstract segments of their experience' (p. 1807). Overall it was anticipated (or aspired to) that 
the EUREKA-system could serve as a representation of the informal relationships between community members. Instead of stories that the technicians exchanged during their breaks, knowledge as part of an expert help system (in the form of tips and tricks helping technicians with problems arising from their repair work on photocopiers) was meant to circulate through the wider 'community'. Knowledge hereby came to be regarded as a thing (or entity) that can circulate in a community rather than as something embedded in the stories that were part of the problemsolving skills of the technicians whom Orr (1996) had reported on. How the templates for describing tips were developed and negotiated was not reported by Bobrow and Whalen (2002). EUREKA-tips were simply depicted as a container or vehicle for the knowledge and experience of the technicians.

Reviewing such projects, Amin and Roberts (2008) pointed to a turn 'towards communities of practice as a driver of learning and knowledge generation across a variety of different working environments' (p. 353). In such frameworks, it was argued that knowledge could be shared following the 'routes prepared by practice' and made possible through 'common embedding circumstances' such as similar tasks and work contexts (Brown and Duguid 2001, p. 203). However, others argued for a shift of attention to a community's shared practice(s) rather than community itself:

I prefer to relate the concept of community of practice to that of community of practitioners [because] a practice and the tradition of a practice do not respect organizational boundaries but instead traverse several organizations. ... Practice, with its materiality, its technological knowledge and its transorganizational character [is what] organizes a community. (Gherardi 2006, p. 108)

With this argument, Gherardi (2006) reversed the causal relationship between community and practice and stated that 'the practice "performs" the community' (p. 108). In so doing she defined community as 'an effect, a performance, realised through the discursive practices of its members' (p. 110):

The practice which ties a community, or several communities, together is what 'performs' the community or the constellation of communities. (Gherardi and Nicolini 2002, p. 422)

Hence, what scholars such as Brown and Duguid and Gherardi and Nicolini highlight is that the notion of community tended to dominate the importance of practice and that it was not an organisational construct called 'community' that needed to be focused on but rather a community's practices.

However, with the rising interest in building and performing digital communities, the notion of practice has undergone a profound translation. Practice became 'reinstrumentalized and reconfigured as a commercial object with specific uses' (Vann and Bowker 2004, p. 41). Labels such as 'good practice' or 'best practice' became a prominent strategy to tackle the abundance of participants and knowledge objects, to filter the informational overload as people often do not know (of) each other (Brown and Duguid 2001) and need some kind of guidance in order to determine relevance, reliability, and quality (Jarke 2017; Scott and Orlikowski 2012; Pollock 2012). What has received less attention is the work of configuring knowledge objects through which practices are meant to circulate in trans-local 
communities and their role for the performance of membership and community. ${ }^{4}$ In order to understand this configuration work better, I now discuss the performance of membership as a practice of accounting and representing a community's shared practice(s).

\subsubsection{Performing Membership Through Accounting and Representing a Community's Shared Practice(s)}

There exists an intricate relationship between the performance of membership and the performance of community: membership (in a community of practice) is performed through shared practices and their accounts. What practice-based studies and practice approaches highlight are that the performance of community includes the performance of membership and what a community is about. The performance of subjects and objects of a community is co-terminus with the performance of the community itself and vice versa.

Munro (2001) considers accounts 'as a display of membership' (p. 474). This is because accounts are not radically distinct from but rather 'parts or tokens' of persons (Mosko 2000, p. 392). This means that the engagement of persons with (a) knowledge object(s) co-produces their identity as members of a community of practice and relates them to others:

Objects exchanged ... are inherently identified with the persons who give and receive them; hence, they are inherently connected with the relations between the persons who reciprocate them to the extent that a person is defined as the composite of relations. (Mosko 2000, p. 382 , emphasis in original)

The production and consumption of accounts of communal practice(s) hence enact community membership. In other words, community members may be held accountable by others for their practice accounts. In addition, accounts tell us something about 'how things ought to be' (Law 1996, p. 295) and hence make visible the underlying assumptions (e.g. concerning the type of community) that are at work in a particular mode of ordering community. Accounts and accounting practices serve as ordering devices as they represent or stand for what is eligible and thereby belongs to a community and what is excluded. Yet these accounts are not just mere representations as they co-construct and co-produce what they are meant to represent.

\footnotetext{
${ }^{4}$ Latour has proposed the term 'immutable and combinable mobiles' (Latour 1987, p. 227) to account for such ordering devices. He was specifically interested in role of immutable mobiles for coordinating networks. The focus of this chapter is on the role of re-configuring such circulation devices for enacting/practicing membership in communities. The space of this chapter does not allow for a more detailed discussion on the differences and similarities of these two interests and concepts.
} 
The process of accounting almost always aims to reduce complexity by categorising social reality. Yet categorisation is a process that leads to what Leigh Star (2010) calls 'intercategory problems' and 'intercategorical objects' which are those 'things that do not fit categories or standards' (p. 609). Over time, all standardised systems throw off or generate residual categories. These categories include 'not elsewhere categorized', 'none of the above', or 'not otherwise specified' (p. 614). They may shift over time and be refined as more and more objects come to inhabit a space. They move 'back-and-forth between ill structured and well structured' (p. 614). Therefore, we need to focus our inquiry on 'the practices or performances of representing, as well as the productive effects of those practices and the conditions for their efficacy' (Barad 2007, p. 49) rather than on accounts or representations as such. This means that we need to attend to the very practices that produce representations and accounts of community and membership in order to understand what they stand for and what the underlying assumptions of a community are.

In many cases, there will be a 'gap between formal representations ... and unreported "back stage" work' (Star 2010, p. 606). Even if community members share representations, there is often 'local tailoring' performed by some members which is invisible to the community as a whole. In particular, for trans-local communities, it is of interest to understand how shared representations come into being and make the work visible that produces such representations. I will argue here that knowledge objects (such as templates) are an ideal starting point for understanding what a community is (supposed to be) about and how participants continuously negotiate their understanding of community by refining them.

Bowker and Star (1999) have argued that membership can 'be described individually as the experience of encountering objects and increasingly being in a naturalized relationship with them' (p. 295). This means that as membership evolves, members become familiar with the specific accounts and representations that a community produces and that are acknowledged as valid. Subsequently knowledge objects (such as templates) become more stable.

To conclude this section: following Gherardi and Nicolini $(2002,2006)$ we need to focus on the practices that perform community rather than take community as a more or less stable assemblage of people sharing a practice. By attending to the production and consumption of knowledge objects as accounts and representations of members' practices, we can learn about how membership is performed in translocal communities. In so doing, the invisible 'backstage work' becomes visible. In the remainder of this chapter, I analyse the work performed to configure templates for representing (supposedly) shared practices within ePractice, a digital assemblage striving to cultivate a European eGovernment community of practice. 


\subsection{Research Methodology and Methods}

\subsubsection{Empirical Site}

The work presented here is based on a 3-year ethnographic study of ePractice: a European Commission project to build a community of European eGovernment practitioners. In June 2007 ePractice joined-up a number of legacy projects, and the European Commission aimed to establish it as the European meeting place for eGovernment practitioners and in so doing produce a European dimension to national eGovernment work.

eGovernment (or electronic government) is the use of information and communication technology (ICT) within public sector organisations in order to provide electronic services to citizens, businesses, and other public sector organisations. Overall eGovernment promised a citizen-centric approach that would bring huge savings and a better integration of public sector bodies by overcoming siloed organisational structures (cf. Bloomfield and Hayes 2009; Ahn 2012; Millard 2010; Rowley 2011). Across the Global North, eGovernment became mainly associated with online services such as driver licence renewal and income tax filing (cf. Ahn 2012).

In building and fostering a 'European eGovernment community of practice', the aim of ePractice was to facilitate the sharing of knowledge and experience amongst eGovernment practitioners across Europe. This was meant to be achieved through a Web portal comprising of a number of online and offline mechanisms such as Web 2.0 features (e.g. public member Web profiles, a community blog), a case study database, workshops, and conferences. By January 2012 over 140,000 people had registered as members of ePractice, over 1550 case studies had been submitted, and over 1800 events had been announced.

With an initial user base of just under 5000 individuals, ePractice grew exponentially throughout the period of my fieldwork. The service was free of charge and users typically worked within the realm of eGovernment-either as civil servants in the public sector, in the private sector (e.g. consulting firms), or academia. Using ePractice, they were able to set up a profile, connect with others, describe their projects as 'ePractice good practice cases', participate in theme-based communities, communicate and discuss via a blog, disseminate studies, activities and events, and also receive up-to-date information about eGovernment across Europe. Furthermore there existed the opportunity to participate in eGovernment-related workshops and conferences. These workshops provided a more formal place for coming together in working sessions but also left considerable room for more informal coffee-break networking interaction. 


\subsubsection{Methodology}

Above, I argued that many studies on 'communities of practice' assume a view of communities as supplements of organisations; interest is directed to crosscommunity activities such as collaboration or knowledge transfer. Communities are taken to be composed of things that can be measured. This 'distal view' of organising is grounded in a 'sociology of being' because it is concerned with 'takenfor-granted states of being' (Cooper and Law 1995). A 'proximal view', in contrast, takes these taken-for-granted entities as outcomes of processes; it focusses on the relations between different entities and the processes that enact and re-enact them. With this approach, the researcher is interested in the performative work of ordering rather than order and looking at relations and recognising these relations as processes rather than durable entities. Hence, rather than being interested in measurable results and outcomes, proximal thinking is interested in the processes and doings that lead to these results (Cooper and Law 1995).

The interest of this paper requires a qualitative approach that attends to the practices, relations, and processes related to communal knowledge objects (Law 2004), and hence it will take a proximal approach. There are many interpretations of what practices may be and how they may be studied. I have followed Mol's (2003) compelling praxiography. For a praxiographer, attending to practices is crucial if wanting to understand how objects come into being, which in my case means attending to the 'tailoring work' (Star 2010) around communal knowledge objects. Following Mol, the identity of objects is never stable but fragile and ever changing; objects are not just brought into being and thereafter remain mute, but they are constantly enacted and re-enacted in practice and thereby multiply.

However, following the practices that bring knowledge objects into being poses methodical challenges in a trans-local setting such as ePractice. My research did not take place in a particular building, not even in a particular organisation. Nevertheless, I went out physically_mainly to Brussels_-and attended workshops where I met people, listened to their presentations, and talked to them during breaks. I also went out virtually - mainly to the ePractice Web portal but also to other websitesand visited project websites, workshop and conference websites, LinkedIn profiles, Facebook, and Twitter. I conducted interviews face-to-face, via Skype, and via telephone. This mixed approach to researching ePractice was, however, not only specific to the research but also a common feature of the diverse communication channels employed by the people I observed and interviewed. The fieldwork was conducted from May 2007 to December 2010. An in-depth study of a specific eGovernment community (eGovMeasureNet ${ }^{5}$ ) was conducted from March 2009 to April 2010. In total, I conducted 73 semi-structured interviews with 58 interviewees and attended 23 events.

My involvement and roles in these events ranged from 'participant observer' to workshop 'rapporteur' to member of an Informal Expert Committee to community

\footnotetext{
${ }^{5}$ The real name of the community has been disguised.
} 
presenter to project staff of the EU-funded thematic network eGovMeasureNet and community facilitator for eGovMeasureNet on ePractice. My participant observation also stretched to the online presence of ePractice: I was a registered user of ePractice and also a community facilitator for eGovMeasureNet. In this position, I created workshop events on ePractice, I posted in the eGovMeasureNet community blog, I uploaded documents, and I corresponded with the eGovMeasureNet community. Throughout my online and offline engagement, I presented myself as a researcher. My public profile on ePractice gave a brief summary of my CV as well as the research focus and interest of my study.

Additionally, I also set up Twitter, LinkedIn and Facebook accounts in order to connect with eGovernment practitioners whom I had met in the realm of ePractice. In all social networking spaces I followed their activities (tweets, groups, events) in order to understand some of the online communication dynamics beyond the ePractice portal. Yet participant observation has its limitations, and I felt that interviews were needed to complement my fieldwork and help me understand what I was encountering through the participants' own sense-making. Most interviews were voice recorded and transcribed. Participation in events was recorded in field notes, and photographs were taken. Further material includes workshop reports, the ePractice blog, and ePractice TV. In addition, the ePractice team made its own survey results and Web statistics available to me. Data was structured and analysed via codification software (ATLAS.ti). All names have been anonymised.

Overall, the long-time involvement in ePractice and the resulting longitudinal study allowed me to follow a proximal research approach that studied ePractice as emergent and becoming. Rather than take the existence of a European eGovernment community for granted, the methodology allowed for insights into how community was enacted. The research methods mirrored the ways of communicating and engaging in ePractice but also the materiality members of ePractice found themselves part of (for example the numerous journeys to Brussels, the attention to online dynamics, and the importance of communal knowledge objects).

\subsection{Analysis}

In the following, I present two vignettes that describe the 'tailoring work' required to produce 'shared representations' within ePractice and how exchange relations were established and performed as part of members' 'accounting practices' (Munro 2001). Key to this work was the development, use, and circulation of templates. In the first vignette, I report on a template that the European Commission developed in order to further 'good practice exchange' amongst European eGovernment practitioners. This is an account in which a coordinating institution developed and reconfigured a template to suit their objective (to build a European community). In the second vignette, I report on a template that was developed by a network of European eGovernment measurement practitioners to facilitate their sharing of practices and to develop a sense of belonging to a community of practitioners. 


\subsubsection{Vignette 1: Translating and Disentangling Practices Through Templates}

Practices cannot simply circulate within a digital network and travel because they are local by definition. A study commissioned by the European Commission about transferability of good practices in eGovernment suggested study tours to the sites of the actual projects because 'the realities of innovation and change in the development of eGovernment on a wider scale represent a much more complicated mesh of events, activities and relationships' (European Commission 2007, p. 55).

Such study tours are an expression of the idea that practices are situated; they are part of evolving exchange relations within a (hopefully) evolving community. Through the participants' co-presence in space and time, an exchange relation is established around mutual attention, interest, and spent resources. An alternative to study tours that follows knowledge management initiatives and exploits the potential of ICTs is the creation of a digital 'knowledge base' to facilitate 'knowledge exchange'. In the case of ePractice, it featured 'ePractice good practice cases' which are written case studies of eGovernment projects. On the ePractice website, the following definition is put forward:

ePractice cases are written summaries of real-life projects or business solutions developed by public administrations, entrepreneurs and corporations. Case studies included in our portal are based on actual experiences, and reading them provides a picture of the challenges and dilemmas faced by the professionals working in eGovernment. ${ }^{6}$

During the interviews, eGovernment practitioners declared repeatedly that knowledge practices may be indeed shared through 'ePractice good practice cases' if they are applicable and transferable to new environments. Good practice needs to translate into the reader's own work context; a reader needs to be able to take useful aspects of other practices and apply them to his or her own work. Hence, the ability of good practice cases to travel and be transferred is seen to depend on what Brown and Duguid (2001) have called 'common embedding circumstances':

The other element is that the information has to be understandable and relevant. So that you can recognise it as something which could be applicable to your area and therefore you can translate that into what you need to know for that work. (Interview with Tom, local government, UK)

Something only becomes a best practice if you can show that what you've done is transferable in some way. It is not like you go into a shop and purchase something; you've got to have the right environment in which whatever you purchase lives. (Interview with Brian, local government, UK)

How much of a project may be revealed in a good practice case if_like in the study cited above-eGovernment projects 'represent a much more complicated mesh of events, activities and relationships' (European Commission 2007, p. 55) than can be translated into a written text? In 2003, the notion of 'ePractice good

\footnotetext{
${ }^{6}$ Retrieved 9 March 2010 from http://www.epractice.eu/info/cases
} 
practice cases' was introduced through the eEurope Awards for eGovernment (from 2005 onwards called European eGovernment Awards): a system of incentives for practitioners to compete and 'share' their eGovernment expertise. Talk and action, practical experience, and local knowledge were accounted for by writing a 'good practice case'. This translation from practice into text was accomplished quite differently from one case to another in terms of, for example, the level of detail, intended target audience, length, and truthfulness.

Within ePractice, a more structured approach was followed in the form of a template that needed to be completed in order to compile an 'ePractice good practice case'. Such a template allowed for comparisons amongst case studies and searches across them. It requested, amongst other things, a short description (abstract), the project's scope, its target audience, the technical and management approach, the policy relevance, and lessons learnt-aspects which the ePractice team 'believe[s] to be of high interest to the ePractice community' (case guidelines). From the beginning of ePractice, the template was provided as an HTML-based online text tool shown in the following screenshot (Fig. 9.1).

The structure or frame that a template provides was positively assessed by case authors and readers alike:

What I found very useful is that the ePractice presentation of the projects is somehow divided in different sections, so that the people who are trying to promote their cases through this ePractice community can follow this pattern and this pattern then can, how to say, make them focus on what is relevant and what is important for a case presentation. So I found this quite useful. (Interview with Marko, NGO, Slovenia)

The template structure hence inscribed a certain reading of accounts and distinguished between what is understood to be 'relevant' or 'important' and what is not. In so doing, the template was more than a simple device that translates eGovernment projects into good practice cases (situated practices into knowledge objects in the form of written text). Rather the template also configured the production and consumption of accounts of good practices and hence the performance of membership itself.

The power of inscribing certain membership practices by providing a template was challenged by a number of ePractice members. They described 'good practice case'-writing as a process that required them to gather information from colleagues and collaborators throughout an organisation. Often MS-Word documents were created and circulated amongst these participants. This information then needed to be compiled, ordered, reviewed, and edited in order to comply with the online template provided by ePractice. Representing practices is not an easy task. One ePractice user suggested making a form available that could be easily circulated in one's own organisation in order to enable people to contribute to the 'case preparation':

I had to do precisely this, because different people had to provide input, check that what I was writing was correct, etc. And I guess, that this is the standard procedure once you publish a case, esp. from public sector organisations. (Comment left on ePractice blog on 31 May 2010) 


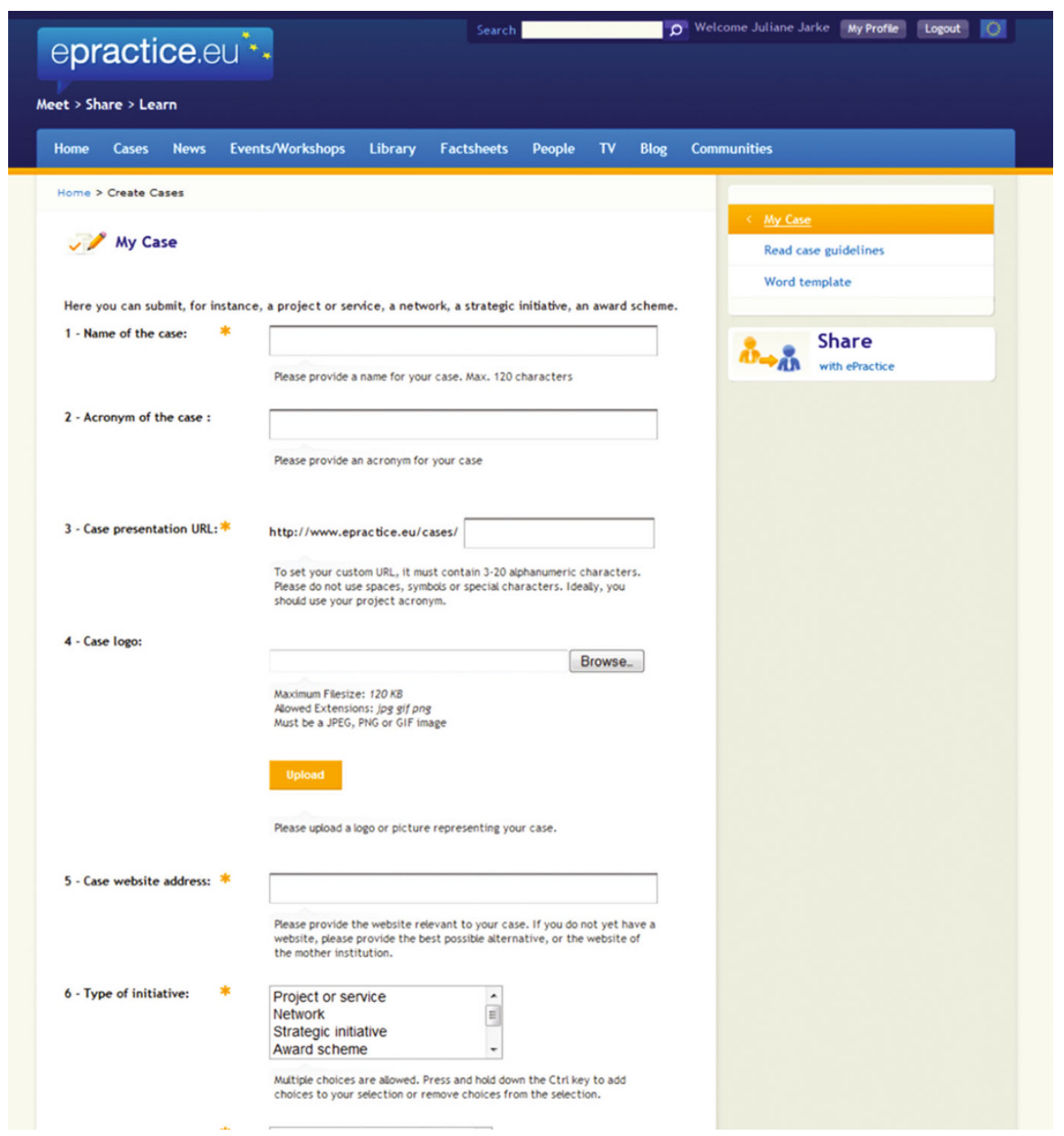

Fig. 9.1 Screenshot of ePractice case template. (Retrieved 12 Jan 2012 from http://www. epractice.eu)

One interviewee (Javier, civil servant in the Spanish regional government) referred to the ability of MS-Word documents to digitally circulate through an organisation in order for 'people to provide input' and 'check' that what was written was 'correct'. He also pointed to the portability of MS-Word documents beyond the workplace as well as their availability and accessibility continuously or in iterative steps. Hence, for ePractice case authors, good practice cases did not simply represent their project or their experience. They were rather an accomplishment, a project in themselves:

Usually these cases are quite complex, they involve a lot of different organisations, and usually it's very hard to capture the whole totality of these complex projects in a one page summary, which is then put on the ePractice portal. (Interview with Marko, NGO, Slovenia) 
The template, in its structured form, does not do justice to the complexity of the various practices. The abundance of people, places, data, objectives, and timings simply lead to overflows. As a result, many case authors, expressed their feeling that they needed to capture more, uploaded additional documents as part of the good practice cases (e.g. videos, slides, tutorials, flyers). This also served to overcome constraints such as word limits or rigid categories in which certain aspects of a 'case' did not fit.

'[C]aptur[ing] the whole totality of these complex projects' is an issue that Star (2010) describes as the 'problem of collecting, disciplining, and coordinating distributed knowledge' (p. 607). She points out that the challenge lies in the decision about which information is 'discarded as unimportant'. The case template does not fit all case authors and their respective projects. Rather they feel that the template 'imposes' a structure and constrains them. Practitioners subsequently created MS-Word documents to frame their content according to the template; they framed 'what they want to say' in order for it to fit the case template structure. Hence a question that needs to be asked is: 'How do [these] forms shape and squeeze out what can be known and collected?' (Star 2010, p. 607). And further, whose decision is it to determine what is to be regarded as relevant or important and what is not? To what extent does a template determine the production and consumption of accounts of membership and subsequently the ways in which community is performed?

As part of an 'upgrading strategy', some of the suggestions elaborated above as well as further features were introduced to ePractice after October 2010. In January 2012 the online template consisted of 33 different headings and allowed the inclusion of further material, including pictures (gallery), presentations via SlideShare, videos via YouTube, or any other files, such as project documentation, directly to the system. ePractice now provides a supporting PDF file with guidelines on how to fill in the case template and a downloadable template in MS-Word format. Cases may be tagged by other ePractice members; they can also be highlighted in one of the ePractice communities or shared via other social networking sites such as LinkedIn.

In the following section, I describe a further case in which a template was continuously reconfigured by a group of practitioners in order to capture their assumed joint practice and cultivate their community. What was striking was that the reconfiguring of such templates and their completion became a membership practice itself.

\subsubsection{Vignette 2: Enacting Joint Practices through and with Templates}

eGovMeasureNet was one of ePractice's biggest 'communities' and was focussed on eGovernment measurements and benchmarking (e.g. comparing eGovernment maturity), initially funded by the EU as a Thematic Network (2008-2010). Its domain of interest and what the community was meant to be about, however, was 
subject to continuous re-negotiation amongst participants. Generally, partners were interested in learning about 'good practices' in the rest of Europe. The heterogeneity of the participants was perceived as rather positive, enabling academics to better 'identify [the] real meaning of their work' and helping practitioners to reflect on what they do through a more 'research-based approach'. There was an aspiration of planting seeds in Europe of what good measurement practices entail.

One of the mechanisms employed by eGovMeasureNet was a 'Measure Template' that was developed to describe 'current practice in measurements of user satisfaction, and impact'. ${ }^{7}$ It was meant to identify 'the common features, and the differences among the methods ... in a collaborative way to support the converging practices' (ibid). The template was 'intended to support the description of eGovernment measurement methods to share the current practices and the experience [of] deploying them'. The term 'vehicle' was used, which ought 'to facilitate the discussion to promote take-up and harmonisation'.

The Measure Template was anticipated to be used as a 'procedural guide' that was going to help make sense of and get to know 'what the other network members were doing'. Simultaneously the Measure Template was seen as a means of supporting community-building through the joint definition of common work practices. It was developed collaboratively and was meant to reveal differences and similarities between, for example, the members' methodological approaches. This straightforward procedure turned out to be highly problematic and caused many controversies.

In the interviews, most interviewees stressed their surprise about the differences they had experienced 2 years into the project. Whereas one of the interviewees located these differences in different work cultures in public sector organisations across Europe, another placed eGovMeasureNet members' different professions (regional government, consultancy) at the fore. The interviews revealed the struggle of participants to produce a single 'good measurement practice' to accomplish successful coordination across sites and between the multiple enactments. The collaboratively developed template failed to coordinate between the various measurement practices; no 'shared representation' had been produced.

The design of the template was initially anticipated to be fairly simple with iterative updates as the project went along. This assumption, however, turned out to underestimate the differences between the measurement practices of eGovMeasureNet members. The jointly developed template had to be refined in several iterations. What was perceived as one of the biggest challenges was identifying the 'right questions'. This was due to the open structure of the template as no section was defined beforehand 'because we didn't really have an idea about what they would look like' (Fredrik, project coordinator).

Questions that arose during the collaboration were: (How) can measurement practices actually be compared? What might be different? What is local and specific, what can be made explicit and is transferable? These were not necessarily things

\footnotetext{
${ }^{7}$ Technical Annex of eGovMeasureNet project proposal, p. 37
} 
members knew, and they were contested. For example, Clara, the project assistant, described in an interview how the template became increasingly detailed as partners negotiated these aspects.

This striving for ever more detailed and fine grained categorisation is what Star (2010) described as 'intercategory problems' which trigger ever more fine-grained categories. In the case of eGovMeasureNet, the resulting template was 20 pages long and very detailed. The template was sent out to eGovMeasureNet members in order to be completed with respect to either measurements they were carrying out in their own organisations or measurements that were taken at the national level of their respective countries.

Giorgio (academic, Denmark) mentioned that the 'real step' was to compare the Measure Templates and referred to a matrix that allowed comparison of 'concrete aspects'. Accordingly, practice exchange (or learning) did not take place by reading a single template but by comparing and analysing several of them. Only through this type of circulation and subsequent exchange was a 'learning community' enacted.

Such comparison allowed searching for patterns among approaches that 'work' in different contexts and identifying similarities and differences. In doing so, sharing practices shifted towards comparing templates and relating the information provided to each other. But no matter how detailed the template became and whether people had been involved at various stages of its development, the Measure Template remained open to misunderstanding and misinterpretation because practitioners related its different categories and questions to different local contexts: the practices of measuring and benchmarking were complex and involved multiple agencies, methods, approaches, and timings.

\subsubsection{Configuring Templates, Performing Community (Membership)}

The above vignettes describe how the European Commission set out to cultivate a community of eGovernment practitioners. Through ePractice they aimed to foster not just any type of European community or network but to establish a 'community of practice'. Their focus is not surprising, given the attention that the concept of community of practice received by managers as a successful way of coordinating distributed settings and leveraging practitioners' knowledge and expertise.

One way of facilitating this cultivation was through the use of templates to describe 'joint work practices'. The importance of practice had been demonstrated by Lave and Wenger (1991) when they introduced the term 'community of practice'. It was taken up by organisation studies and management scholars, who argued that for distributed forms of community, a coordination of practices was required. Coordinating practices through the templates is a specific way of attending to the challenge of facilitating the travelling of local and situated practices. 
However, there is an important difference between the two vignettes: in the first vignette, the template was configured by the ePractice team; in the second vignette it was the practitioners themselves that negotiated the structure of their communal template. In the first vignette, the ePractice team reacted-at their own discretionto feedback from registered ePractice members. The continuous reconfiguration followed a particular mode of ordering-one that was concerned with sharing knowledge and facilitating learning amongst members of ePractice. There was also another task assigned-to make the community and performance of membership explicit and visible by accounting for a joint practice. Hence, it was not just any ephemeral community that the ePractice team wanted to cultivate but a visible one. Visibility was in part achieved through documented accounts of performing community membership. Interviewees from the European Commission repeatedly stressed the importance of proving 'that exchange has happened'. The way these accounts were imagined to represent and stand for the envisaged community configured ePractice accordingly.

In the second vignette, the template was configured (or scripted) by eGovMeasureNet members themselves. Working on the template and amending it was experienced as a form of collaborative practice and communal sense-making (determining what eGovernment measurements are about). The 'sending back and forth', the circulation of the template throughout its development process, already established an exchange relation in which, for example, categories and legitimate practices were negotiated. Hence, despite the above mentioned complications and differences, eGovMeasureNet members felt a sense of belonging and were keen to mutually engage in joint activities. In order to reach a communal understanding and exploit different backgrounds, interviewees emphasised repeatedly that they had 'to learn to talk to each other'. This learning process was a very important part of community-building. Moreover, members not only needed to learn to talk to each other but also had to make their work visible to others. These very practices became part of performing membership. Overall, the Measure Template served as a frame for demarcating the eGovMeasureNet community and the understanding of its joint domain of interest. Hence the framing worked in two ways: (1) the framing of benchmarking and measurement projects to fit the scope of eGovMeasureNet, and (2) the adaptation of the boundaries of the Measure Template itself to the unanticipated breadth of activities and all the things that had remained 'intercategory problems' and 'intercategorical objects'. This means that the created 'good practice cases' were not merely a collection of the community's knowledge and shared practices but rather continuous reconfigurings of what valid representations of supposedly joint practices are. 


\subsubsection{Configuring Templates, Performing Exchange Relations}

Both vignettes described practices of making work practices visible and of sharing practices digitally, which are distinctively different from learning and knowledge sharing in co-located encounters (as described by Lave and Wenger (1991) and Lave (2011)). Many of the associations that Orr (1996) described so vividly in his account of a community of photocopy repair technicians were absent. This is why digital accounts became so important: a shared repertoire of resources and accounts had to be developed, e.g. through the Measure Template that also included conceptual objects such as 'eGovernment measurements' and 'benchmarking'.

In both vignettes, a practice or a field of practice was at first passively shared, then actors driving community development efforts attempted to share experiences stemming from this practice in a more active way. In the first vignette, the active part of sharing was restricted to the exchange of experiences (filling out templates). In the second vignette, practitioners were actively involved in setting the rules of sharing (developing the templates). The first vignette demonstrates how interaction at the local level was fostered (through collecting and preparing the 'relevant data'), while the second vignette demonstrates how templates may foster trans-local interaction.

Hence, performing ePractice as a community demanded the production and consumption of specific accounts of membership performance, such as the development and circulation of templates. 'Good practice cases' were not alien to ePractice members but formed part of their professional work identity (of being a connected and networked European eGovernment practitioner). In making circulation possible, these accounts were what participants exchanged and what enabled 'exchange relations'. They were exchanged and-at the same time-constituted exchange relations. What may be found in the empirical material above is hence a different way of displaying membership than through the performance of a joint work practice. What can be found is rather the production and reconfiguration of accounts of its performance. What constitutes the exchange relations are practitioners, their diverse work practices and understandings, their ideas and motives, the materialities of ePractice as well as the interests of funding bodies such as the European Commission. The accounts in the form of the Measure Template display the work that was done in order to form and perform an eGovMeasureNet community. The display of membership was accomplished by contributing to these efforts of associating a diverse set of actors in a particular way. The exchange relations were not simply established between community members but rather enabled the circulation and association of a variety of heterogeneous entities. 


\subsection{Conclusion: Community by Template?}

This chapter attended to how the communities of practice concept has been taken up by managers and policy makers in trans-local contexts. Although the concept was developed for co-located communities, it was transferred to distributed settings. In such settings, the sharing of practices is not necessarily active, and the performance of community not necessarily tied to their sharing. Some of the ambiguities of the original concept became problematic as it is not sufficient to passively and translocally share a practice-practitioners need to enter exchange relations in order to perform community membership.

The two vignettes demonstrate how community is understood by policy makers and managers as a form of organisation that needs to be cultivated and coordinated. Continuing on the success of the concept of communities of practice, a focus of such striving became the sharing of experiences (and 'good practices') in order to foster community-building. Hence, the sharing of practice came to be seen as co-terminus with enacting community. In a trans-local context, this meant-for the actors responsible for building community-a focus on how practices may be shared actively. One answer to this challenge was to describe local practices in standardised templates. However, different ways of organising the sharing of knowledge objects (e.g. who are the actors that define the structure of templates or how do they determine what counts as 'good practice') resulted in different forms of communality.

To conclude, digital communities of practice are not cultivated through the passive sharing of practices but rather through the performance of exchange relations. A crucial role for establishing and enacting exchange relations are knowledge objects such as templates. They are more than a 'common body of knowledge' (du Plessis 2008) or 'community knowledge pool' (Lesser and Storck 2001). Rather, they play a crucial role in the forming (and performing) of community by defining a communal practice and making membership performance visible. Hence, knowledge objects such as templates are not simply a means to actively share practices but rather a means for enacting membership. They enable exchange relations amongst individual practitioners, concepts such as eGovernment, practices, projects, and technologies that stand for a community's domain of interest, the diverse work practices and understandings of members, their ideas and motives as well as the interests of funding bodies such as the European Commission.

Acknowledgements I would like to thank Karen Kastenhofer and Susan Molyneux-Hodgson for their constructive feedback and patience throughout the process. Furthermore, I thank Andreas Breiter, Andreas Hepp and his lab (in particular Matthias Berg, Anke Offerhaus and Susi Alpen) for providing feedback on an early version of this chapter. I am grateful to Theo Vurdubakis, Niall Hayes and Lucas Introna for their guidance during my $\mathrm{PhD}$ research and for encouraging me to expand it. 


\section{References}

Ahn, M.J. 2012. Whither e-government? Web 2.0 and the future of e-government. In Web 2.0 technologies and democratic governance. Political, policy and management implications, ed. C.G. Reddick and S.K. Aikins, 169-182. New York: Springer.

Amin, A., and J. Roberts. 2008. Knowing in action: Beyond communities of practice. Research Policy 37 (2): 353-369.

Barad, K. 2007. Meeting the universe halfway: Quantum physics and the entanglement of matter and meaning. Durham: Duke University Press.

Bloomfield, B.P., and N. Hayes. 2009. Power and organizational transformation through technology: Hybrids of electronic government. Organization Studies 30 (5): 461-487.

Bobrow, D.G., and J. Whalen. 2002. Community knowledge sharing in practice. The Eureka story. Reflections 4 (2): 47-59.

Bowker, G.C., and S.L. Star. 1999. Sorting things out: Classification and its consequences. Cambridge, MA: MIT Press.

Brandi, U., and B. Elkjaer. 2011. Organizational learning viewed from a social learning perspective. In Handbook of organizational learning and knowledge management, ed. M. Easterby-Smith and M.A. Lyles, 23-42. Chichester: John Wiley.

Brown, J.S., and P. Duguid. 1991. Organizational learning and communities-of-practice: Toward a unified view of working, learning and innovation. Organization Science 2 (1): 40-57.

- 2001. Knowledge and organization: A social-practice perspective. Organization Science 12 (2): 198-213.

Cooper, R., and J. Law. 1995. Organization: Distal and proximal views. Research in the Sociology of Organizations 13: 237-274.

Cox, A. 2005. What are communities of practice? A comparative review of four seminal works. Journal of Information Science 31 (6): 527-540.

du Plessis, M. 2008. The strategic drivers and objectives of communities of practice as vehicles for knowledge management in small and medium enterprises. International Journal of Information Management 28 (1): 61-67.

Easterby-Smith, M., and M.A. Lyles. 2011. The evolving field of organizational learning and knowledge management. In Handbook of organizational learning and knowledge management, ed. M. Easterby-Smith and M.A. Lyles, 1-22. Chichester: John Wiley.

European Commission. 2007. High-level report -provide e-government good practice portability. Brussels, available at: www.euforum.org/IMG/pdf/D1.6-Final_report-v1.pdf: European Commission. accessed 27 July 2010.

Fischer, G. 2001. Communities of interest: Learning through the interaction of multiple knowledge systems. Proceedings of the 24th IRIS conference, pp. 1-14.

Gherardi, S. 2006. Organizational knowledge: The texture of workplace learning. Malden, MA: Blackwell Pub.

Gherardi, S., and D. Nicolini. 2002. Learning in a constellation of interconnected practices: Canon or dissonance? Journal of Management Studies 39 (4): 419-436.

Haas, P.M. 1992. Epistemic communities and international policy coordination. International Organization 46 (1): 1-35.

Jarke, J. 2015. "Networking" a European Community: The case of a European Commission egovernment initiative. ECIS 2015 Completed Research Papers. Paper 86.

- 2017. Community-based evaluation in online communities: On the making of 'best practice'. Journal of Information Technology and People 30 (2): 371-395.

Lave, J. 2008. Epilogue: Situated learning and changing practice. In Community, economic creativity, and organization, ed. A. Amin and J. Roberts, 283-296. Oxford: Oxford University Press.

- 2011. Apprenticeship in critical ethnographic practice. Chicago: Univ. of Chicago Press. 
Lave, J., and E. Wenger. 1991. Situated learning: Legitimate peripheral participation, learning in doing. Cambridge: Cambridge Univ. Press.

Latour, B. 1987. Science in action: How to follow scientists and engineers through society. Harvard University Press.

Law, J. 1996. Organizing accountabilities: Ontology and the mode of accounting. In Accountability: Power, ethos and the technologies of management, ed. R. Munro and J. Mouritsen, 283-306. London: Cengage Learning EMEA.

- 2004. After method: Mess in social science research. London: Routledge.

Lesser, E.L., and J. Storck. 2001. Communities of practice and organizational performance. IBM Systems Journal 40 (4): 831-841.

Millard, J. 2010. Government 1.5-Is the bottle half full or half empty? European Journal of ePractice 9: 1-16.

Miller, D. 2010. An extreme reading of Facebook. Working papers series \#5. OAC Press.

- 2011. Tales from Facebook. Cambridge/Malden: Polity Press.

Mol, A. 2003. The body multiple: Ontology in medical practice. Durham: Duke University Press.

Mosko, M.S. 2000. Inalienable ethnography: Keeping-while-giving and the Trobriand case. Journal of the Royal Anthropological Institute 6 (3): 377-396.

Munro, R. 2001. Calling for accounts: Numbers, monsters and membership. The Sociological Review 49 (4): 473-493.

Orr, J.E. 1996. Talking about machines: An ethnography of a modern job. Ithaca: ILR Press. 2006. Ten years of talking about machines. Organization Studies 27 (12): 1805-1820.

Østerlund, C., and P.R. Carlile. 2005. Relations in practice: Sorting through practice theories on knowledge sharing in complex organizations. Information Society 21 (2): 91-107.

Pollock, N. 2012. Ranking devices: The socio-materiality of ratings. In Materiality and organizing: Social interaction in a technological world, ed. P.M. Leonardi, B.A. Nardi, and J. Kallinikos, 91-112. Oxford: Open University Press.

Roberts, J. 2006. Limits to communities of practice. Journal of Management Studies 43 (3): 623-639.

Rowley, J. 2011. e-Government stakeholders-Who are they and what do they want? International Journal of Information Management 31 (1): 53-62.

Scott, S.V., and W.J. Orlikowski. 2012. Great expectations: The materiality of commensurability in social media. In Materiality and organizing: Social interaction in a technological world, ed. P.M. Leonardi, B.A. Nardi, and J. Kallinikos, 113-133. Oxford: Open University Press.

Star, S.L. 2010. This is not a boundary object: Reflections on the origin of a concept. Science, Technology, and Human Values 35 (5): 601-617.

Swan, J., H. Scarbrough, and M. Robertson. 2002. The construction of 'communities of practice' in the management of innovation. Management Learning 33 (4): 477-496.

Vaast, E., and G. Walsham. 2009. Trans-situated learning: Supporting a network of practice with an information infrastructure. Information Systems Research 20 (4): 547-564.

Vann, K., and G.C. Bowker. 2004. Instrumentalizing the truth of practice. In The Blackwell cultural economy eader, ed. A. Amin and N. Thrift, 40-57. Oxrford: Blackwell Publishing Ltd.

Wenger, E., R. McDermott, and W.M. Snyder. 2002. Cultivating communities of practice: A guide to managing knowledge. Boston: Harvard Business School Press. 
Open Access This chapter is licensed under the terms of the Creative Commons Attribution 4.0 International License (http://creativecommons.org/licenses/by/4.0/), which permits use, sharing, adaptation, distribution and reproduction in any medium or format, as long as you give appropriate credit to the original author(s) and the source, provide a link to the Creative Commons license and indicate if changes were made.

The images or other third party material in this chapter are included in the chapter's Creative Commons license, unless indicated otherwise in a credit line to the material. If material is not included in the chapter's Creative Commons license and your intended use is not permitted by statutory regulation or exceeds the permitted use, you will need to obtain permission directly from the copyright holder. 